\title{
Should They Stay or Should They Go Now?
}

The Discretionary Character of Poor Relief, Settlement and Removal in the Low Countries

\author{
MARJOLEIN SCHEPERS
}

Poor migrants in early modern Europe were often sent away to their place of origin to prevent them from becoming a burden on their place of residence. The laws of 'settlement' determined to which place they had to return to apply for poor relief. Despite increasing centralisation, and even the introduction of national legislation in the nineteenth century, settlement remained framed within the local parish or municipality. This paper argues that continuity existed in local belonging and the autonomy of local communities in negotiations on the removal of migrants. It analyses why some migrants were 'removed' and others were not, and to which extent and why local communities deviated from legislation. Analysing case studies of eighteenth-century Flanders, which have been particularly well documented, helps to place the predominantly anglocentric historiography on settlement and removal in a broader framework and also helps to further our understanding of the systems of inclusion and exclusion of migrants.

Arme migranten werden in vroegmodern Europa vaak weggezonden naar hun plaats van herkomst, opdat zij niet ten laste van hun woonplaats zouden vallen. In de wetten van onderstandswoonst, ook wel onderstandsdomicilie genoemd, werd bepaald naar welke plaats zij teruggezonden moesten worden. Hoewel er toenemende centralisering plaatsvond en er in de negentiende eeuw nationale wetgeving hierover werd ingevoerd, bleef onderstandswoonst gekaderd in de lokale parochie of gemeente. Dit paper betoogt dat er continuïteit bestond in het thuishoren in de lokale gemeenschap (belonging) en dat er lokale autonomie bleef bestaan in het beslissingsmakingsproces over wie uitgesloten werd en wie niet. Het 
artikel onderzoekt expliciet waarom sommige migranten werden teruggezonden en andere niet, en in welke mate en waarom lokale gemeenschappen hierin het heft in eigen handen namen en afweken van de regelgeving. De analyse van uitzonderlijk goed gedocumenteerde case studies uit achttiende-eeuws Vlaanderen helpt de voornamelijk anglocentrische historiografie over settlement en removal in een breder kader te plaatsen en meer in het algemeen om de systemen van in- en uitsluiting van migranten beter te begrijpen.

\section{Introduction}

In the year 1763, at the end of summer, Josephus and Pieter Verbeke were sent away by the overseer of Beveren (district of Furnes), their place of residence. They were moved by carriage with their wives and children to Wervik, a town along the Leie River on the border between France and Flanders, which happened to be the birthplace of the two brothers. Neither family had sufficient means to care for themselves and they needed help. To make matters worse, Josephus's wife was pregnant at the time of the removal. The magistrates of Wervik were appalled to see them arrive. They had not been consulted nor notified about the removal and vehemently objected to it, arguing that everyone was supposed to be allowed to settle where they wanted and that there was free choice of place of residence. ${ }^{1}$

The removal of poor migrants was a contested subject in eighteenthcentury Flanders. There was no national poor law regarding mobility and settlement, but many different regulations existed at the local level. Local parishes were responsible for poor relief and the place where someone was eligible for relief was called his or her 'place of settlement', also known as 'onderstandswoonst' or 'onderstandsdomicilie' in Dutch and as 'domicile de secours' in French. According to an agreement that was concluded for West Flanders in 1750, the 'settlement' of the brothers Verbeke was located in their birthplace Wervik and that is why they were removed to that place when they needed help. But the system was discretionary in nature: Wervik argued that the brothers should stay in Beveren, where there were more employment opportunities, whereas Beveren had decided that they should be sent away.

This article focuses on the agency of local communities in including and excluding the mobile poor. Debates on removal are used here as a proxy for analysing these systems of inclusion and exclusion because they left some leeway for negotiations: the criteria of settlement were generally more strictly defined than the conditions for removal. ${ }^{2}$ Analysing local practices,

1 Stadsarchief Veurne (SAV), Oud Archief (OA), 1122:

Armenwezen. Varia betreffende armenwezen,

1614-1751, letter from mayor of Wervik to the board of the castellany of Furnes, 9 September 1763 . 
and especially the rhetoric used in negotiations, I will argue that there was considerable local autonomy in these matters in the Low Countries throughout the eighteenth century and beyond.

\section{Historiography}

Historiography on poor relief and settlement has mostly been concerned with England and Wales, where a national Poor Law was introduced in the late seventeenth century. In recent decades, research into the Poor Law in England and Wales has witnessed a revival as historians have started to focus more on the 'spatial dynamics of welfare', analysing regional and local variations. ${ }^{3}$ Relief provisions in the south-east of England are, for example, generally considered to have been more generous and inclusive than those in the industrialising north. Other authors focused on intra-regional differences and argued that variations in inclusiveness were high even among neighbouring parishes. ${ }^{4}$ The spatial approach similarly resonates in settlement debates. Historians have, for example, demonstrated that parishes made agreements on not removing migrant poor to their place of settlement, thus allowing for 'out-parish' or 'non-resident' relief. Insofar as this permitted the poor to reside in places where labour demand was higher, it contributed to maintaining a reserve labour supply. For sending communities it allowed saving on relief expenses as well as transport costs if overall income opportunities of the poor were higher in their place of residence than of settlement. ${ }^{5}$ Local or regional

see inter alia James Stephen Taylor, 'A Different

Kind of Speenhamland: Nonresident Relief

in the Industrial Revolution', Journal of British

Studies 30: 2 (1991) 183-208; Steven King, “'It Is

Impossible for Our Vestry to Judge His Case into

Perfection from Here": Managing the Distance

Dimensions of Poor Relief, 1800-1840', Rural

History 16:2 (2005) 161-189; Steven King, 'Poor

Relief, Settlement and Belonging in England

1780 s to 1840 s', in: Steven King and Anne Winter,

Migration, Settlement and Belonging in Europe,

1500-1930s (New York 2013) 81-101; Tim Hitchcock,

Adam Crymble and Louise Falcini, 'Loose,

Idle and Disorderly: Vagrant Removal in Late

Eighteenth-Century Middlesex', Social History

39:4 (2014) 509-527.

3 Peter Jones and Steven King, 'Obligation,

Entitlement and Dispute: Navigating the English
Poor Laws 1600-1900', in: Steven King and Peter Jones (eds.), Obligation, Entitlement and Dispute under the English Poor Laws (Cambridge 2015) 1-19, 7; Steven King, 'Welfare Regimes and Welfare Regions in Britain and Europe, c.1750s to 186os', Journal of Modern European History 9:1 (2011) 42-65; George R. Boyer, An Economic History of the English Poor Law, 1750-1850 (Cambridge, Cambridge University Press 1990) 85-121.

4 Bhyung-Khun Song, 'Parish Typology and the Operation of the Poor Laws in Early NineteenthCentury Oxfordshire', Agricultural History Review 50:II (2002) 203-224; Steve Hindle, On the Parish? The Micro-Politics of Poor Relief in Rural England, c.1550-1750 (Oxford 2004).

5 Taylor, 'A different kind'. 
variations were thus also reflected in the decisions on who should stay and who should go. The research field has continued to develop with increased interest in the mobility aspect of the poor laws, enabled by new digital research methods mapping mobility as well as research into conceptions of 'belonging', i.e. the connections of individuals with a certain place or community. ${ }^{6}$ These recent developments have opened up new fields to explore in settlement history.

Another recent development is the broadening of the scope to the European framework of welfare, resulting in edited volumes with case studies of different European countries, regions and cities. ${ }^{7}$ It is now generally accepted that the English welfare system was not unique and that comparably extensive systems existed on the continent. ${ }^{8}$ Coastal Flanders, for example, had elaborate settlement regulations and witnessed the introduction of poor taxes in the eighteenth century. ${ }^{9}$ So far, several case studies have appeared on cities and regions within the Low Countries with promising results, linking local autonomy in settlement and relief decisions to urban labour markets and to different types of rural economies. ${ }^{10}$ Religion is another factor of interest in these case studies. I would however argue that the attention for religious diversity has somewhat overshadowed the existence of settlement regulations in the Northern Netherlands: although several publications

Keith D.M. Snell, Parish and Belonging.

Community, Identity and Welfare in England and Wales, 1700-1950 (Cambridge 2006); Steven King, 'Friendship, Kinship and Belonging in the letters of Urban Paupers 1800-1840', Historical Social Research 33:3 (2008) 249-277; See also the conference 'Urban Belonging: History and the Power of Place' (London 2017).

Ole Peter Grell, Andrew Cunningham and Robert Jutte (eds.), Health Care and Poor Relief in 18th and 19th Century Northern Europe (London 1997); Andreas Gestrich, Lutz Raphael and Herbert Uerlings (eds.), Strangers and Poor People. Changing Patterns of Inclusion and Exclusion in Europe and the Mediterranean World from Classical Antiquity to the Present Day (Frankfurt 2009); Justin Colson and Arie van Steensel (eds.), Cities and Solidarities: Urban Communities in Pre-Modern Europe (New York 2017); King and Winter, Migration, Settlement and Belonging in Europe.

8 Anne Winter and Thijs Lambrecht, 'Migration, Poor Relief and Local Autonomy: Settlement
Policies in England and the Southern Low Countries in the Eighteenth Century', Past E Present 218:1 (2013) 91-126.

9 Ibidem; Thijs Lambrecht and Anne Winter, 'De vele gezichten van zorg. Armoede en armenzorg op het platteland in het Graafschap Vlaanderen tijdens de achttiende eeuw', Tijd-Schrift 7:1 (2017) 44-57; Thijs Lambrecht and Anne Winter, 'An Old Poor Law on the Continent? Poor Taxes and Village Conflict in Eighteenth-Century Coastal Flanders in a Comparative Perspective', Economic History Review (Early View Online 2017). Marco van Leeuwen, 'Overrun by Hungry Hordes? Migrants' Entitlements to Poor Relief in the Netherlands, 16th-2oth Centuries', in: King and Winter (eds.), Migration, Settlement and Belonging, 173-203; Nick Van den Broeck, Anne Winter and Thijs Lambrecht, 'Preindustrial welfare between regional economies and local regimes: Rural poor relief in Flanders around 1800', Continuity and Change (in press, 2018). 
mention the early-nineteenth-century 'wet op de domicilie van onderstand', or earlier ordonnances in, for example, Holland and Friesland, there has been little research into settlement practices in the Dutch Republic. ${ }^{11}$ Historians of poor relief in the Netherlands have often stressed that religious communities had to take care of their 'own poor' - Catholics, for example, generally could not turn to public poor relief. ${ }^{12}$ However, despite the importance of religion in governing welfare eligibility, the laws of settlement also applied to religious charity. Moreover, access to public or religious relief also differed between cities. ${ }^{13}$ This article therefore proposes to further analyse the spatial variation in the Low Countries by looking at the daily practices of settlement and belonging, thus going beyond the normative sources. The peculiar characteristics of regional economies and religious diversity can help to further our understanding of settlement and belonging in practice.

Theory

Turning now to the question why communities included certain migrants and excluded others, the settlement and removal literature contains both explanations pointing to structural factors and explanations highlighting individual agency. Boyer, for example, argues that selective removal policies existed and were determined by the interests of the communities involved. Parishes did not implement settlement and removal law in the same way, nor did they necessarily follow 'the letter of the law' when, for example, paupers were granted non-resident relief. Boyer mostly explains this out of economic concerns, such as the needs of the labour market. He points out that

12 Joke Spaans, Armenzorg in Friesland 1500-1800. Publieke zorg en particuliere liefdadigheid in zes Friese steden Leeuwarden, Bolsward, Franeker, Sneek, Dokkum en Harlingen (Hilversum 1997); Joke Spaans, 'Kerkelijke en publieke armenzorg voor en na de scheiding tussen kerk en staat', in: Jan de Bruijn (ed.), Geen heersende kerk, geen heersende staat. De verhouding tussen kerk en staat 1796-1996 (Zoetermeer 1998) 127-144.

13 Maarten Prak, 'Goede buren en verre vrienden. De ontwikkeling van onderstand bij armoede in Den Bosch sedert de Middeleeuwen', in: Henk Flap and Marco van Leeuwen (eds.), Op lange termijn. Verklaringen van trends in de geschiedenis van samenlevingen (Hilversum 1994) 147-170. 
demographic and occupational characteristics were key to this selectivity. ${ }^{14}$ King, on the other hand, states that parishes acted differently towards individuals with similar characteristics, arguing that 'one pauper with a given set of circumstances would be removed and another with a roughly identical set would not'. ${ }^{15}$ What we might call the 'structural' view, focusing on the economic conditions in the parish, indeed does not explain why one single unwed mother was removed upon destitution, whereas another single unwed mother was allowed to stay. King, having analysed pauper letters and additional poor law sources extensively, therefore suggests that factors such as religion, the individual moral standing as well as personal chemistry all impacted removal decisions. ${ }^{16}$ He does not deny that the nature of labour demand was one of them, but rather adds a personal layer of emotions, morality and discretion to the structural view.

This reminds us of a more contemporary debate on the discretionary nature of migration decisions, such as the individual agency of decision makers implementing migration policy. ${ }^{17}$ The theory of 'street-level bureaucracy' is often referred to in this research. It explains deviations between policies and practices by analysing the agency of the 'men on the spot' enforcing these policies. ${ }^{18}$ There was some leeway for individuals to implement policy according to their personal judgement. Personal characteristics of these street-level executives influenced their actions but, vice versa, what happened on the ground also influenced policymaking. This article adds a historical Ancien Régime perspective to these contemporary migration history debates on the divergence between policies and practice. Focusing on the negotiations considering relief, settlement and removal will help to elucidate the role of agency and discretion. ${ }^{19}$

\section{Materials and methods}

Taking into account these theories of local autonomy, selectiveness and individual agency, this paper proposes to analyse the different interests involved in deciding who was included and who was excluded. I will do so by focusing on diverging local regulations or agreements on settlement and removal (meso-level), and by analysing the negotiations concerning

Boyer, 'An economic history', 256-257.

King, 'Poor Relief, Settlement and Belonging', 98-99.

King, 'Poor Relief, Settlement and Belonging', 98-99.

Tycho Walaardt, Geruisloos inwilligen.

Argumentatie en speelruimte in de Nederlandse asielprocedure, 1945-1994 (Hilversum 2012);
Joanne van der Leun, 'Excluding Illegal Migrants

in The Netherlands: Between National Policies and Local Implementation', West European

Politics 29:2 (2006) 310-326. https://doi. org/10.1080/01402380500512650.

18 Michael Lipsky, Street-Level Bureaucracy: Dilemmas of the Individual in Public Service (New York 1980).

19 See also Hindle, On the Parish?, 361-449. 
the removal of individuals in daily practice (micro-level). This focus on the micro-level of daily practices will help us to determine to what extent local communities followed or diverged from legislation and also which factors played a role in determining whether an individual should be included or excluded from local relief provisions. The selected sources for this second part are derived from a case study of the Concordat of Ypres, complemented with comparisons to other cases found in the literature. The Concordat was a bottom-up agreement applicable in a border region that included parts of eighteenth-century France and Flanders, and the largest local agreement found so far. The sources of this Concordat, which have been preserved in multiple archives, provide unique insights into the functioning of settlement in daily practice. This availability of an abundance of sources on the local level is unique for the Low Countries, especially for the early modern period. ${ }^{20}$

This article is the first to analyse how such practices and negotiations functioned in the Low Countries. ${ }^{21}$ Unlike for England, we cannot crosslink data from removal orders to settlement certificates, settlement examinations and pauper letters, simply because bureaucracy was less elaborate and fewer sources have survived in any systematic way. There was no standardised organisation of the local poor relief institutions in the early modern period. ${ }^{22}$

Regions: A Microhistory of Out-Parish Relief in Bulskamp, 1768-1796, Rural History (in print, 2018).

21 framework. There has, however, been some research on the practices of warranty letters inter alia by Davids and Winter, but these studies had a different approach and did not include analyses of the rhetoric employed in individual cases. Davids, 'Migratie te Leiden'; Anne Winter, 'Caught between Law and Practice: Migrants and Settlement Legislation in the Southern Low Countries in a Comparative Perspective, c. 17001900', Rural History 19:2 (2008) 137-162; Anne Winter, 'Settlement Law and Rural-Urban Relief Transfers in Nineteenth-Century Belgium: A Case Study on Migrants' Access to Relief in Antwerp', in: King and Winter, Migration, Settlement and Belonging, 228-249. The functioning of the Concordat in terms of settlement will be discussed in greater detail in the results selections below. Another limitation is that the state of the research in the Low Countries is not as advanced as in England, especially with regards to the archiving: most 
It is nevertheless feasible to analyse the rhetoric used in the negotiations during conflicts between parishes over an individual's removal, albeit without conclusive information on the outcome of these discussions. Before elaborating on these sources in greater detail, this paper will first discuss the local autonomy of cities and regions to create and enforce their own settlement legislation.

\section{The meso-level: settlement practices in the Low Countries}

Settlement has always had a local framework. On the European continent, this local framework dates back to the Reformation period, when Charles $\mathrm{v}$ issued a decree in 1531 stating that the poor should turn to their own parish when in need. Which parish was considered one's own was determined by settlement legislation. For the Southern Low Countries, a 1617 decree established that settlement was in the birthplace while three years' residence elsewhere transferred a migrant's settlement to that new place of residence. Several more specific imperial decrees were also issued in the eighteenth century for regions such as Flanders and Brabant. Regions in the Northern Low Countries also often referred to the 1531 law. There, relatively comparable settlement legislation existed in several provinces, where some form of settlement by residence was common throughout the early modern period. ${ }^{23}$

The French occupation implied a centralisation and harmonisation of these regulations: for the first time a national settlement decree was issued. National laws, however, continued to maintain that settlement was located in the municipality. Although the criteria of settlement did vary over time, settlement remained framed within the local parish (or municipality after the French reforms) and financed from local resources. The first true breach with the principle of local settlement occurred only in 1876 in Belgium, when a new decree provided provincially financed relief to migrants who had left their municipality of settlement but had not yet obtained settlement elsewhere. That decree established a communal fund on provincial level to finance the care of these 'non-belonging' poor, relieving local communities of this responsibility, while maintaining the local framework of settlement. It was not until the twentieth century that a national system of welfare was

sources can be found in archival dossiers titled

'relief, various'. For the local variations in income and distribution structures of local poor relief institutions, see Thijs Lambrecht and Anne Winter, 'An Old Poor Law on the Continent? Agrarian Capitalism, Poor Taxes and Village Conflict in Eighteenth-Century Coastal Flanders', Economic History Review (Early View Online 2017) doi:10.1111/ehr.12611; as well as Van den Broeck, Winter and Lambrecht, 'Preindustrial welfare'. Landschapsordonnantie of 166 o to the 1682 decree of the States of Holland, cf. Cornelis van Voorst van Beest, De katholieke armenzorg te Rotterdam in de 17de en 18de eeuw (The Hague 1955) 12-22; Spaans, Armenzorg in Friesland, 77-88, 125, 265, 374. 


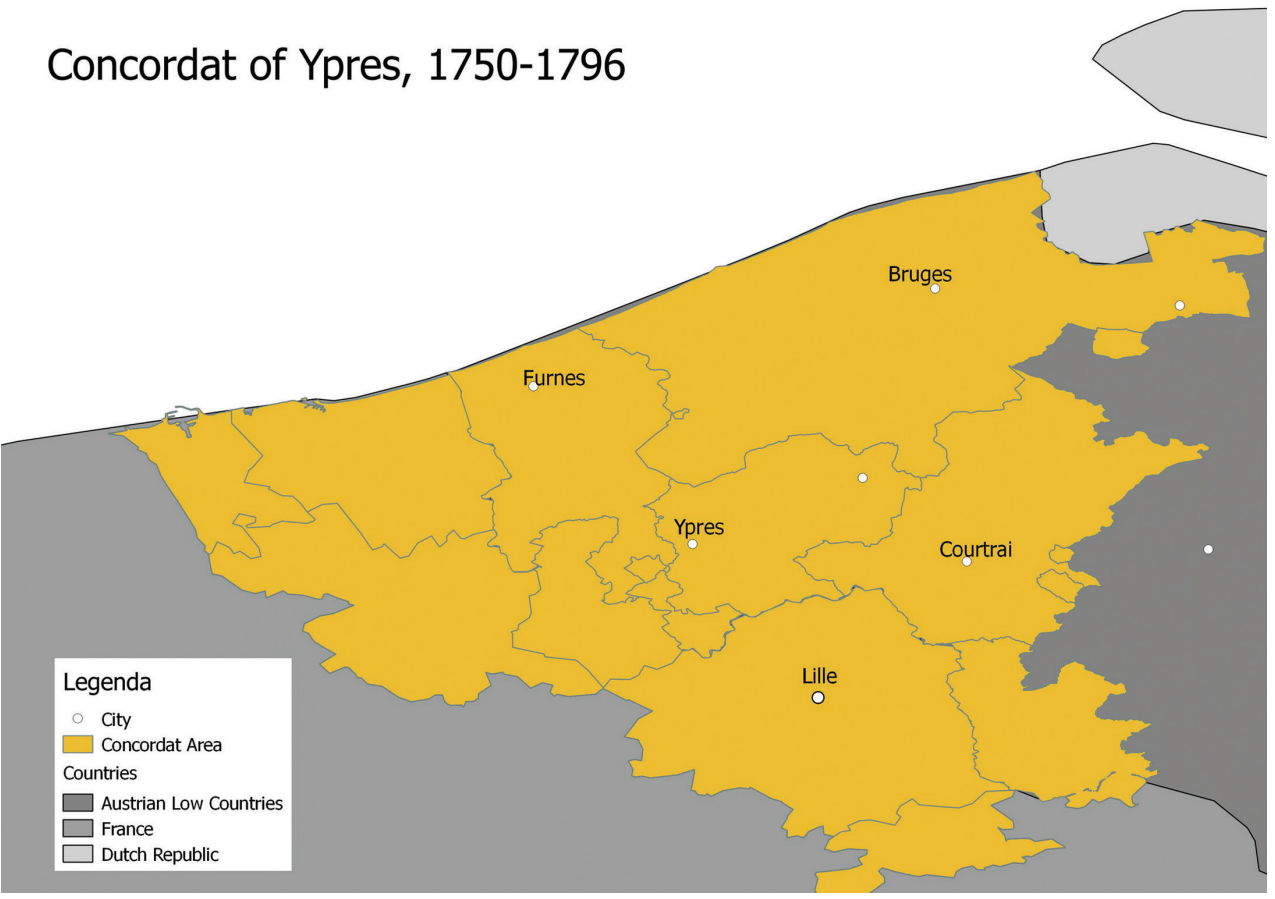

$\Delta$

Region of the Concordat of Ypres, map made by the author. Cartographic data of Ancien Régime Flanders and France provided by Sven Vrielinck and Torsten Wiedemann of STREAM-project (Ghent University).

Source: Rijksarchief Brugge, Registers Brugse Vrije, 574: 'Register waarin de parochies en heerlijkheden van het platteland het algemeen reglement voor steun aan de behoeftigen aannemen, opgemaakt te leper op 6 juni 1750', 30. 
introduced. In the meantime, none of the revolutions, the French period, the creation of the Belgian nation-state in 1830 or the Dutch constitution of 1848 had altered the fundamental local principle of poor relief and settlement. ${ }^{24}$

\section{Local exceptions to 'central' legislation}

Throughout the eighteenth and nineteenth centuries, several municipalities decided that central settlement legislation did not suffice. Often the legislation was considered too vague or different parishes held varying interpretations, or the regulations failed to address local problems regarding mobility and poverty. All sorts of local exceptions and deviations, therefore, existed to central regulations. Several of such local practices in England have been discussed by historians. There, cost-benefit considerations and interests in stimulating labour mobility have been identified as the main motive for rural parishes to interpret or deviate from settlement legislation according to local needs. ${ }^{25}$ Such economic examples are also abundant in the Low Countries. Leiden, for example, issued an ordinance in 1716 stating that all newcomers had to provide a pledge that they would not become a burden on the urban relief funds if they became poor. These measures were taken because of the influx of 'alien poor, beggars, scroungers, vagrants, lazy and other nonuseful persons', which threatened the availability of relief funds for the 'true and worthy' poor. ${ }^{26}$ The pledge was materialised in the form of an acte van cautie, a warranty letter which newcomers had to present before settling. Such warranty letters were implemented in many Dutch and Flemish cities and formed a type of identity document for the poor, as a means to deal with the influx of migrants and to establish their settlement. ${ }^{27}$ Amsterdam however sedentarisering en stad-platteland-tegenstellingen.

Evolutie en betekenis van de wetgeving op de onderstandswoonst in België (einde achttiende tot einde negentiende eeuw)', BTNG-RBHC XXI, 3-4 (1990) 483-534, 512. For more information on settlement legislation in the Low Countries, see Paul Bonenfant, Le problème du pauperisme en Belgique à la fin de l'Ancien Régime (Brussels 1934); Van Damme, 'Onderstandswoonst'; Cornelis van Voorst van Beest, De katholieke armenzorg; Spaans, Armenzorg in Friesland; Petrus Bernardus Antonius Melief, De strijd om de armenzorg in Nederland, 17951854 (Groningen 1955)87-88; Stijn van de Perre, 'Als eene zaak van hoog belang. Het armenzorgbeleid in de Nederlanden (1814-1818)', in: Frank Judo and Stijn Van de Perre (eds.), Belg en Bataaf. De wording van het Verenigd Koninkrijk der Nederlanden (Antwerp 2015) 257-310, 286; Albert L. Kort, Geen cent te veel. Armoede en armenzorg op ZuidBeveland, 1850-1940 (Hilversum 2001);' Herman Coppens, 'Een arme eend in de vreemde bijt. Het overheidsoptreden tegenover binnenlandse migranten in de regio Antwerpen tijdens het late ancien régime (ca. 1550 tot 1790)', Taxandria 81 (2009) 137-175. See for example Taylor, 'A Different Kind'. Davids, 'Migratie te Leiden', 147. Winter, 'Caught between Law', 144-145; Van Leeuwen, 'Overrun by Hungry Hordes?', 189-19o; Davids, 'Migratie te Leiden'; Coppens, 'Een arme eend'. 


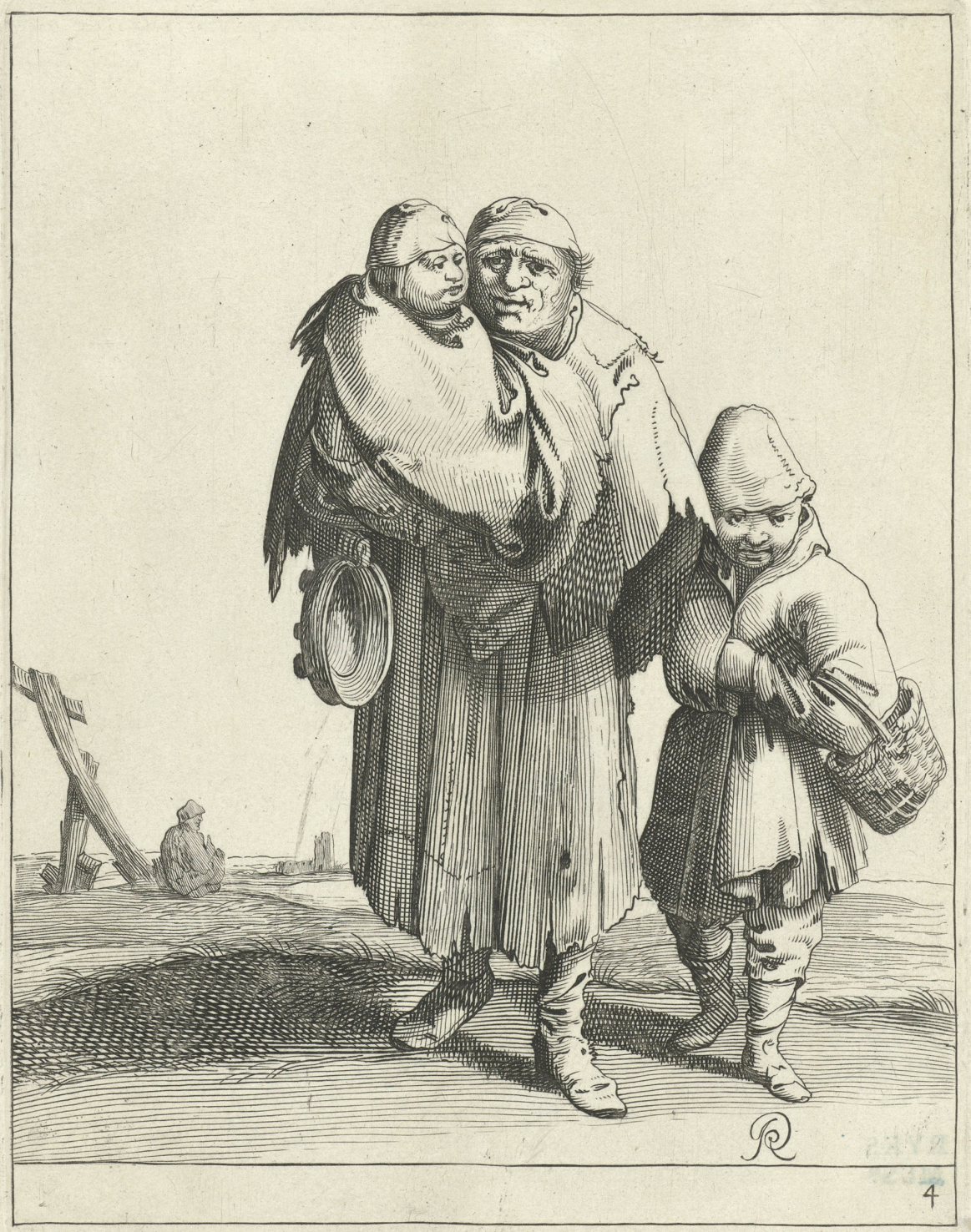

$\Delta$

'Drie bedelaars' (1634-1638), etching and engraving by Pieter Jansz. Quast, Collection Rijksmuseum, Amsterdam. http://hdl.handle.net/10934/RMooo1. COLLECT.341426. 
opted not to make these warranty letters obligatory, exactly because the city considered their requirement a hindrance to free mobility. The city had no interest in restricting immigration, because it needed immigrants to feed the supply of dockers and sailors for the port and fleet. ${ }^{28}$ Despite this stimulation of mobility, the city did restrict migrants' access to welfare. The heads of settlement in Amsterdam were based on seven years' residence instead of the general six years in most other Dutch cities. Amsterdam and Leiden both tried to regulate and limit relief expenses, but in a context of different challenges and interests. ${ }^{29}$

Local institutions thus took matters into their own hands in enacting legislation. The province of Friesland, where most inhabitants were Protestants, stated that all church members should first and foremost apply to their respective religious communities for relief. Those in need without membership of a religious institution could address the public relief system, where general settlement legislation prevailed. ${ }^{30}$ In the city of 's Hertogenbosch, in the mostly Catholic region of Brabant, relief would be provided to all the city's inhabitants, regardless of their religion or native status. ${ }^{31}$ This shows how religious diversity did not necessarily have precedence over settlement in the Northern Netherlands. Cities and rural regions throughout the Low Countries formulated local regulations to deal with their specific local challenges regarding mobility and poverty.

The history of the 1750 Concordat of Ypres introduces another factor to these motives for arranging settlement regulations at a local level: reciprocity between parishes and across borders. This cross-border convention created in 1750 was a bottom-up agreement and operated independently of central governments. It was created after the French occupation over Ypres and Furnes ceased and essentially sought to continue harmonisation of settlement legislation throughout the region. The Concordat aimed to limit the conflicts on migrants' settlement by creating a clear, uniform and harmonious regulation across the region. There were high levels of internal and cross-border mobility, related to the micro-mobility of the labouring poor, more specifically day labourers as well as seasonal labour mobility. The Concordat, then, had also sprung from economic motives. Coastal Flanders was an agrarian capitalist area, with increasing concentration of landownership in the hands of large labour-hiring farmers who could benefit from a flexible labour supply for the sowing and harvesting seasons. The Concordat would render migration regulation and arbitration regarding relief applications more efficient and help to limit the expenses on poor relief,

Van Leeuwen, 'Overrun by Hungry Hordes?', 190.

Marco van Leeuwen, Bijstand in Amsterdam ca. 1800-1850. Armenzorg als beheersings- en overlevingsstrategie (Zwolle 1992), 113-114.
30 Spaans, Armenzorg in Friesland, 329, 374.

31 Prak, 'Goede buren', 160. 
making sure the region benefitted from labour mobility without carrying the burdens of the labourers' welfare. ${ }^{32}$ But motives relating to the transnational aspect clearly played a role too: the Concordat was strongly inspired by the early-eighteenth-century decrees of northern France to which Ypres and Furnes, which were among the districts that had created the Concordat, had also been subjected. Moreover, the border communities of Ypres, Furnes and Northern France were the main propagators of this cross-border collaboration. For the Concordat members, tackling the problems concerning poor migrants in a cross-border solution thus appeared more important than following central legislation. ${ }^{33}$

Central governments thus left quite some leeway for local administrations to interpret and implement settlement legislation at their own discretion. Or, as a contemporary legal scholar put it, the civil law on settlement defined the local parish or municipality as the most apt level of governance to implement this legislation, because they had the tools to ascertain whether an individual actually belonged in the community. ${ }^{34}$ The variations in local enforcement of settlement could inter alia be explained by the characteristics of the host society, for example the needs of the labour market, but also geopolitical considerations stemming from the fear of migrants misusing the system by shopping for rights, or installing a uniform system to prevent future conflicts. ${ }^{35}$

\section{The micro-level: removal negotiations in the Concordat}

Having discussed the co-existence of local and central settlement legislation, the next section of this article zooms in on the decision-making on the individual level, discussing how the negotiations concerning settlement and especially removal developed in daily practice. It focuses on discussions between parishes about where individuals belonged, that is, the conflicts over an individual's removal such as the above-discussed case of the Verbeke brothers. Such conflicts occurred often, even after the Concordat had been designed to prevent them. Despite the attempt to create a clear and coherent agreement, there was an ambiguity in the regulations which allowed both for removals of migrants and the distribution of out-parish relief. ${ }^{36}$ This

unpublished paper presented at the European

Social Science History Conference (Valencia 2016).

34 Den Tex and Van Hall, Nederlandsche jaarboeken, 213 .

35 Schepers, 'Van zieke visverkoper'.

36 Both removal and out-parish relief were common in the Concordat. Generally, residence parishes provided relief to an individual in need and only afterwards would they try to get reimbursements 
vagueness was created by a disparity between the first and second articles of the agreement. The first article stated that every poor person was free to move and settle in a place that best suited his interests, essentially advocating free mobility. Warranty letters were also abolished to stimulate mobility. The second article stated that each person upon becoming poor should return to his or her birthplace to be relieved there. Although this clause advocated removal, the free mobility clause also allowed for out-parish relief to take place. ${ }^{37}$

The archives hold individual case files, or 'pauper conflicts', which contain correspondence between relief institutions, villages and cities as well as local district governments (kasselrijen) concerning the relief application of an individual..$^{38}$ They concern individual relief requests that resulted in arguments between residence and settlement parishes over who was liable to pay and whether the individual was allowed to stay or should be 'removed', i.e. sent back to his or her settlement parish. Whereas such individual conflicts would earlier have been resolved in court, the Concordat had installed a system of internal arbitration. ${ }^{39}$ The general idea was that this would limit the costs of arbitration. The internal conflict-resolving system means that the sources are ideal for contextualisation because they contain more information than judiciary files and also include the viewpoints of multiple agents in a single conflict.

\section{Street-level negotiations and extra-legal arguments}

Many of the letters discussing the options regarding removal or out-parish relief comprised more information than strictly necessary, employing a

if it concerned an immigrant with settlement elsewhere. Settlement was as a rule located in the birthplace, but the agreement contained many exceptions for married women (following the status of their husbands), underage children (following the status of their fathers until age of maturity), children born out of wedlock (following the status of their mothers until adulthood), orphans (following the status of the last living parent, or the deceased father) and even casual birth (following the status of the father). This elaborateness stemmed from the objective of limiting the number of conflicts. For more information on the Concordat, see Schepers, 'Welfare'; Schepers, 'Regulating poor migrants'.
$37 \mathrm{SAV}, \mathrm{OA}, 1122$, letter from the mayor of Wervik to the board of the castellany of Furnes, 9 September 1763.

38 Many of these sources have been saved and can be found in different archives, probably because they formed proof of the jurisprudence of local parishes. The sources however are not inventoried or organised as a selection, but are rather spread over different dossiers in several local archives. Algemeen Rijksarchief Brussel (ARA), Archief van de Geheime Raad, Cartons 1285 A, Folder 2.3, 'Reglement concernant l'entretien des pauvres' (6 June 1750). 
rhetorical style. The authors employed a discourse that ventured beyond the legal regulations. These arguments did not refer to legal texts and are therefore defined here as 'extra-legal' arguments. They rather alluded to different values, related to the interpersonal relations between the individuals and parishes involved. In other words, there was a discourse in use, diverging from the strictly legal arguments for removal, which recurred in many situations. Examples of such rhetoric include 'to make sure humanity does not suffer that this unhappy poor woman would be abandoned on her own, deprived of any relief, we pray you, gentlemen, to instruct the administrators of Westvleteren, her birthplace, to provide for her without any delay ${ }^{30}$, or 'because it is woeful to perish along streets or roads while one may not demand for his bread anywhere'. ${ }^{41}$ Parishes used different types of rhetoric according to their interests in keeping or removing an individual from their community. These discourses mainly concerned the deservingness of the individual and where he or she 'belonged' as well as the more politicaladministrative relations between the parishes involved.

Deservingness is a concept employed in historical debates to describe the extent to which a relief applicant was considered to 'deserve' assistance. ${ }^{42}$ Residence parishes of migrants, for example, first and foremost tried to prove that the relief applicant was not a beggar or vagrant and instead was an honest, hardworking or religious person, especially when some provisional assistance had already been provided that they hoped to recover from the person's place of settlement. Another strategy that parishes employed was demonstrating that relief actually formed the last resort. In the case of Joannis Linders, for example, the castellany of Bergues St. Winoc (which his residence parish of Tetegem was subject to) wrote to the castellany of Cassel for advice on whether Tetegem or the birth parish in the Furnes region or yet another parish was liable for relief and whether removal was allowed. On the need for relief, the letter stated:

\section{[...] that he was burdened with a woman and a child; that his wife furthermore was about to give birth, that he had been in bed for seven weeks due to an illness of which he had not entirely recovered, which was the reason why it was not possible for him to earn anything to sustain his family, in short that they}

Thumanité ne souffre pas que cette pauvre malheureuse soit abandonnée a elle-même privée de tout secour, nous vous prions messieurs de vouloir bien ordonner aux administrateurs de westvleteren son lieu natal d'y pourvoir sans retard', in letters concerning the settlement and removal of Dorothea Benedicta Luyssens: SAV, OA, letter from castellany of Cassel to castellany of Furnes, 23 November 1788. All translations in this article are by the author of this article.

41

'Want het jommerlick (?) is lanckst straeten of wegen te vergaen terwijl men nergens sijn broot en magh vragen' in letter concerning Benedictus de Lange in SAV, OA, 1122: letter from Hondschoote city to castellany of Furnes, s.d.

42 Hindle, On the Parish?, 379-397. 
were in want of everything and that they had been reduced to extreme misery, which was confirmed by Mr. Deriq, priest of the said parish Teteghem. ${ }^{43}$

These letters generally claimed the unavoidability of the provision of relief but often also related to preliminary provisions of relief by the parish of residence seeking reimbursement from the assumed settlement parish. The rhetoric was thus used to justify these actions so as not to discuss the actual justification of the provision itself. Deservingness formed a rhetorical argument integral to the negotiation process.

Another theme often addressed in such rhetoric relates to belonging in the sense of kinship and friendship closely related to belonging and designating the integration of a migrant into the host society, or his or her remaining link with the home community. Authorities, for example, pointed out an immigrant's local family and kinship networks which could function as alternative support systems but also formed a reason to reside in the same place. Another reason for a person to stay in a community was economic rootedness because of employment. Native or alien ancestry was also employed as an argument to claim local belonging as were less tactile criteria such as the position of the individual in the local community, for example as someone who was held in good esteem locally. ${ }^{44}$ These were all introduced as reasons to remove or not remove an individual from his or her parish of residence. Piety could also be used to underscore someone's belonging, as a case in eighteenth-century Leeuwarden shows. Removal was not an issue here, rather which relief institution was supposed to assist a poor widow. She did not have enough money to buy clothes for herself or her children and had therefore not visited her Mennonite church in years. The Mennonite charity did not want to assist her and stated she should be excommunicated and turn to the urban poor relief institutions for assistance. When the overseer could demonstrate that poverty was the only reason she had not shown up in church and that her religious zeal was thus strong as ever, the Mennonites eventually agreed to assist her. This case demonstrates how access to relief, or even membership in that sense, was judged on the basis of non-tactile, enfant; que sa femme d'ailleurs étoit a tout moment prête d'accoucher, qu'il a été détenu au lit malade pendant sept semaines, dont il n'etoit point encore entièrement rétabli de qui étoit cause qu'il ne lui étoit point possible de pouvoir gagner quelque chose pour sustenter sa famille en un mot qu'il leur manquait de tout et qu'ils étoient réduit a la dernière misère, ce qui étoit certifié par le Mr deriq curée de la ville paroisse de la dite paroisse de Téteghem'. SAV,
OA, 235: Briefwisseling van de magistraat met de onderscheidene parochies wegens onderstand $\mathcal{E}$ onderhoud der behoeftigen, 1746-1792, letter from castellany Bergen St. Winocx to castellany Cassel, 3 February 1770.

44 For an elaborate analysis of friendship, kinship and belonging in 'pauper letters', i.e. relief requests written by the poor, a form of ego-documents different from the sources employed here, see King, 'Friendship, Kinship and Belonging'. 




$\Delta$

'Wandelaar onderweg' (1605-1653), etching and engraving by Gillis van Scheyndel (I), Collection Rijksmuseum, Amsterdam. http://hdl.handle. net/10934/RMooo1.COLLECT.347237. 
non-concrete, non-objective values. ${ }^{45}$ The discourse instead related to values considering the individual in question. The use of such rhetoric in negotiations cannot be explained by purely structural analyses, but rather alludes to a more individual, emotional history.

Thirdly, the letters contained arguments not only about the individual but also about the relations between the parishes concerned. Parish overseers tried to persuade their counterparts by promising to act similarly in future situations. Some parishes within the Concordat, for example, asked a court for advice on the conflict, which functioned as an additional means to exert pressure on the other side - even though judicial consults were not recognised as arbitration procedures within the Concordat. ${ }^{46}$ Letters also referred to past relations, for example stating how a parish had always treated the other community rightly in previous conflicts and did not appreciate the lack of response to their letters. ${ }^{47}$ The historiographical literature does indeed recognise the reciprocal relations between parishes and power balances as a relevant factor in discussions of removal. ${ }^{48}$

A more in-depth analysis of out-parish and removal cases is needed that systematically compares the relations between parishes and considers the differences between rural and urban institutions, as well as the influence of different economic conditions or migration patterns. The present study does show, however, that relations between the characteristics of the migrant, the home society and the host society are essential to understanding variations in rhetoric on the individual level.

\section{The persuasiveness of extra-legal rhetoric}

The discussed types of extra-legal arguments did have some form of persuasive power. For example, in cases where castellany district boards (kasselrijbesturen) were asked to intervene more than once these boards adopted the extra-legal rhetoric on belonging or deservingness. The castellany of Furnes, when intervening in a conflict between its subject parish Beveren and the French parish of Hondschoote concerning Pierre Beele, argued that the parish members of Beveren 'do not pretend at all to oppose the required assistance of aforesaid Pierre Beele following that necessity requires it' and stated that Pierre Beele 'is still strong enough to work, at least partially, for his own maintenance and that

son, where the advice of the court of Cassel was

asked and used as a means to put pressure on

the other side. SAV, OA, 235, letter from castellany

of St Winocxbergen to castellany of Cassel, 3

February 1770.
47 In 24 percent of the analysed individual cases, one of the parishes promised reciprocity in future cases or used former actions as an argument to demand similar actions from their opposite numbers.

48 See for example King, 'It is impossible'. 
of his family'.49 The castellany board thus used the same rhetoric concerning belonging and deservingness as the parish of Beveren. Beele was eventually assisted by Beveren on the condition that he took his residence there..$^{0}$

In a similar vein, the castellany of Courtrai adopted the discourse employed by its opponent, the city of Nieuwpoort, in a case involving the fishmonger Johannes van Laethem. The castellany of Courtrai had intervened on behalf of its parish Herzeeuw and stated that 'the claim of those of Nieuwpoort had a legal basis'. ${ }^{51}$ Van Laethem should be relieved by Herzeeuw and should not be removed from Nieuwpoort. It eventually turned out that the region of Courtrai had already left the Concordat, which meant that the central legislation of settlement by residence (the aforementioned 1750 regulation) was valid: Van Laethem had strictly speaking gained settlement in Nieuwpoort and should thus be relieved by Nieuwpoort. Removal to Herzeeuw was thus, legally speaking, a non-discussion. While the castellany had copied the rhetoric of Nieuwpoort, there was actually confusion about the day-to-day application of the legislation..$^{2}$

\section{Strategic use of discourse?}

In the case of Van Laethem and in about 40 percent of the letters in the source selection, it seems as if legislation was not understood properly or the concerned institutions were not fully aware of the relevant legal framework. This has been observed for the English case as well. ${ }^{53}$ But in addition to the above-described correspondence that appears to stem from confusion, the correspondence also lays bare motives behind the employed rhetoric. Ill but otherwise able-bodied men, for example, were usually claimed by both the residence and settlement parishes as 'belonging'. This related to the 'utility' of these men, considering that they could continue to work and pay taxes after recovery and thus were contributing members of their residence society. But this reasoning could go either way, according to the interests of the communities: settlement parishes, for example, could also argue for outparish relief for able-bodied men because of the employment opportunities in the parish of residence, as was the case in the discussion concerning Pierre

\section{castellany Furnes, 22 May 1750; idem, letter from} Beveren parish to Hondschoote, 23 May 1750.

51 ' $[C]$ et demande de ceux de Nieuport est fondée en justice', RAK, BP, 5948, letter from castellany Kortrijk to Herzeeuw parish, 26 August 1791. 
Pinthin, where his settlement parish argued for him to stay in his residence parish: '[...] we therefore believe that he can subsist with the work of his hands and also through the support that we are giving him, which makes that it would be better for him to live there than here, consequently we pray you in the best interest of this man to leave him in the same parish'.54

Considerations of efficiency, reciprocity or the prevention of high costs of removal also played a role, as well as the prevention of possible dependency of future generations on the parish. But the considerations were not necessarily all practical in nature. Moral issues also played a role, which we can observe in the custom of residence parishes providing relief in advance - which they hoped to be reimbursed for-before even contacting the settlement parish, for example in the discussed cases of ill but otherwise ablebodied men who could return to work after recovery. 55

\section{The 'unwanted'}

The strategies behind the employed rhetoric become especially clear when we focus on the 'unwanted' category, or the 'negative use' of such arguments in the case of people who could be considered unwanted, i.e. those who were likely to incur increasing expenses or who (supposedly) constituted a 'nuisance' in the community. Ignaes Bouden, a resident of the textile city Roeselare, was, for example, not included in his residence parish nor in his settlement parish. His situation had become untenable after he had started to suffer from 'immobility or illness of mind ${ }^{96}$ The local parish overseer considered him delusional and demanded that his parish of settlement, the rural parish of Alveringhem, come pick him up. Roeselare threatened that Bouden would otherwise be locked up in prison at Alveringhem's expenses. Bouden had refused to work, considered everything as his property and threatened to set fire to his house. When he was eventually put in prison, he stole food from his fellow inmates and refused to sleep neither 'on beds nor straw'. He maintained that 'everything belonged to him' and threatened that he would set fire to the prison. ${ }^{57}$ Although his residence parish Roeselare provided some relief for his sustenance out of humanitarian considerations, the settlement parish never came forth to collect him or reimburse the parish. This man was not considered as belonging to the community by either parish. le travail de ses mains et aussi par le secours que nous luy donnons, ce qui fait qu'il y trouve mieux à vivre qu'ici, en consequence nous vous prions en faveur de cet homme de le laisser dans la meme paroisse', SAV, OA, 1122, letter from Wervik city to castellany of Furnes, 7 March 1769.
55 Schepers, 'Van zieke visverkoper'.

56 'immobiliteit ende crankheit van geeste': SAV, OA, 1122, letter from Roeselare to Alveringem, 16 September 1750.

57 Idem, letter from Roeselare to Alveringem, 11 November 1750 and letter from Roeselare to Alveringem, 21 November 1750. 
His perceived insanity meant that no parish wanted to be held liable for his relief, nor wanted him to reside in the community.

The case of Adrien George on the other hand initially developed as a case of an old man who was no longer able to work, i.e. a member of the deserving poor. His residence community Beveren (in the rural district of Furnes) emphasised his local belonging and deservingness, since he had always worked as a journeyman shoemaker. Beveren therefore demanded that George's birth parish Tielt initiate out-parish relief. But the rhetoric of belonging and deservingness soon gave way to less-inclusive rhetoric when Tielt replied that George had been banned from his birth parish because of criminal behaviour. Tielt no longer considered him part of the community and refused to pay for his relief. ${ }^{58}$ Although the outcome of this case is unknown, it is clear that the rhetoric shifted after the plot twist when Beveren learned he was a criminal. When he was still considered an old, infirm, deserving man, the parish argued for Tielt to send out-parish relief, but when the overseer found out he had a criminal conviction the discourse changed.

This undesirability of certain categories also often resonated in the cases of single unwed mothers. Their presence in the community could add to local relief costs, because they were generally unlikely to sustain themselves and their children by work. Moreover, children born out of wedlock were dependent on their mother's settlement status and would impose an additional burden on their birth parish after becoming adults. The case of the widow Hennebel, who had two children born out of wedlock, resulted in a heated discussion in which her parish of residence, Westvleteren, accused the assumed settlement parish (i.e. her birth parish) of having 'maliciously' denied having adopted the Concordat of Ypres. Westvleteren threatened to take the matter to arbitration at the Council of Flanders and referred to other cities and castellanies which had agreed with the solution Westvleteren had proposed. The parish tried to prevent being stuck with Hennebel. ${ }^{59}$

A close analogy can be made here with a case described by Van Leeuwen in his analysis of relief provision in nineteenth-century Amsterdam. Widow Sousterman, whose husband had recently deceased, subsequently moved with her children from Amsterdam to her nearby parents' village Heusden, where she could rely on family support to help sustain her children. Sousterman, however, fell ill upon arrival and was no longer able to care for her family. She was provided relief by Heusden, which was reimbursed by Amsterdam. The Sousterman family, however, was ordered to move back to Amsterdam to be relieved under the city's supervision. In this case, the woman's good name and moral behaviour were proof of her deservingness, arguments that were 
used in other above-mentioned cases as well. Sousterman 'was entitled to the largest empathy possible'. ${ }^{60}$

The discourse employed in this 1824 case bears similarities to those discussed earlier for the eighteenth-century southern Low Countries. Although the research employed here does not pretend to be exhaustive, we can conclude that comparable rhetoric was used in claims to local rights or local assistance. Whereas belonging, deservingness and promises of reciprocity were adduced in the case of individuals the local community had an interest in, in the case of the rather 'unwanted' individuals parishes rarely argued for the necessity of their presence in the community. The construction of an individual's identity or belonging and the decision on whether the presence of this person was wanted or not by settlement and residence parishes were thus partially dependent on sometimes conflicting interests in these communities.

\section{Conclusions}

This article has demonstrated that 'local belonging' played an important role in the distribution of poor relief in the Low Countries. Despite the increasing centralisation of social policy and welfare, settlement remained a status attached to the local community and continued to be defined locally throughout the early modern period and into the nineteenth century. Zooming in on local practices shows that many local communities took matters into their own hands and deviated from more centrally issued legislation to address local challenges. As in England, the creation of such local regulations often had economic motives, such as cost-benefit considerations, preventing increases in poor relief expenses or regulating labour mobility. Religion also played a role, especially in the northern Low Countries. Moreover, the case of the Concordat of Ypres has shown how geopolitical considerations of reciprocity and harmonisation across borders were also relevant.

The weight or relevance of this local agency becomes especially visible on the micro-level of daily decision-making processes regarding conflicts between parishes on individuals' settlement and removal. These negotiations appealed to values other than the strict legal clauses, such as family (re-) unification and previous employment. These stemmed from a broader range of motives, such as friendship, morality and economic rootedness, which were not necessarily involved when targeting immigrant groups in local regulations. Local communities followed or diverged from legislation in daily practice, even if regulations were actually already designed to address local challenges as was the case in the Concordat. The arguments used in 
these negotiations often referred to a different set of values than the strictly legal reasons to grant settlement or allow removal. This 'extra-legal' rhetoric also had some degree of persuasive power. Although the nature of the source material renders it difficult to make conclusive statements on the effectiveness of such rhetoric, I hope to have shown that there are recurring patterns in the claims of inclusion and exclusion that often deviated from legislation.

These patterns persisted throughout the eighteenth century and even extended into the nineteenth and twentieth centuries. Settlement remained located in the parish or municipality despite ongoing centralisation and state formation. Local communities therefore continued to wield power to decide who belonged and who did not. A national welfare system was introduced only in the twentieth century and still retained local traits such as the local ocMw (Public Centre for Social Welfare) in Belgium or municipal social benefits services in the Netherlands. During the eighteenth and nineteenth centuries and the early twentieth century, several factors continued to play a role in determining whether an individual should be included or excluded from local relief provisions. These could be structural factors such as the labour market and demographic characteristics of the communities involved but also factors related to the individual and his or her standing in the community, appealing to deservingness, belonging and especially morality. Finally, the relations and especially power balances between the involved parishes also played a role. Several parishes complained, for example, that Lille always removed Flemish destitute migrants but never took back its own poor. $^{61}$

All in all, the main factors determining inclusion or exclusion were the characteristics of and relations between migrants, sending communities, and receiving communities. The question remains to what degree such triangular negotiations concerning inclusion and exclusion were specific to the Low Countries and, conversely, what about them was universal or identifiable elsewhere too. This question deserves further research in a European framework. The Low Countries are an interesting case because of the availability of different ecologies in a relatively small area, as well as the relevance of religious diversity in poor relief and charity. More comparative research on this region would not only further the debates on poor relief but also have implications for the understanding of the changing dynamics of inclusion and exclusion, as well as the persistence of local belonging in the face of centralisation and nationalisation. 
Marjolein Schepers (1990) is a PhD candidate in History at Vrije Universiteit Brussel and the University of Ghent. She is specialised in migration history and has previously conducted research on undocumented migrants in the Netherlands, the history of immigrant integration in Flanders and colonial and postcolonial migration in Belgium. Her current PhD project focuses on rural-urban relations in migration regulation and access to poor relief in eighteenth-century Flanders and France. Recent publications include 'Regulating Poor Migrants in Border Regions: A Microhistory of Out-Parish Relief in Bulskamp (1768-96)', Rural History 28:2 (2018), 'The Societal Turn: Historicising Future Society', Tijdschrift voor Sociale en Economische Geschiedenis (in print 2018, with Esther Beeckaert et al.) and 'Van zieke visverkoper tot arme vreemdeling. Mobiliteit en armoede op de drempel van het revolutietijdvak', Jaarboek De Achttiende Eeuw (2017). Email: marjolein.schepers@vub.be. 